\title{
The Majesty of Human Effort in Ernest Hemingway's The Old Man and the Sea
}

\author{
Sabah Abdul Hameed Shakury \\ Department of English, Jadara University, Jordan \\ E-mail: dr_shakury@yahoo.com
}

Received: 17-06-2016

Accepted: 24-08-2016

Published: 02-01-2017 doi:10.7575/aiac.ijalel.v.6n.1p.35

Advance Access Published: November 2016

URL: http://dx.doi.org/10.7575/aiac.ijalel.v.6n.1p.35

\begin{abstract}
The purpose of this study is to discuss the effort of the leading character of Heminway's The Old Man and the Sea, as an example of human effort, in a context which shows his sense of isolation in the society. Santiago's awareness of his individual role in the universe permits him more authentic effort. The major task of the researcher is to discuss Santiago's consistent effort to restore his character and thereby renew his life and be once again part of the community. The researcher's interest is to show which goal Santiago tries to achieve: pride or endurance?
\end{abstract}

Keywords: Santiago, majesty, pride, endurance, defeat, triumph, marlin

\section{Introduction}

Ernest Hemingway's The Old Man and the Sea is a study of human effort. With the help of his old character, Santiago, Hemmingway portrays the majesty which resides nowhere but inside human beings. Although the old man is in a place where to prove himself and confront with a dilemma or decision, he feels love and respect for all aspects of life: people, creatures of the sky and sea and to the very elements of the universe itself.

Santiago's effort is shown when he starts struggling against the fish, "He rested sitting on the unstepped mast and sail and tried not to think, but only to endure" (Hemingway, Old Man, 35). Then he advises himself, as self admonition, saying, "... think of it always. Think of what you are doing. You must do nothing stupid" (37). The character of Santiago seems to signify the code of human effort who must pursue his quest alone to maintain his self-respect. As Robert Weeks remarks: "Santiago fights his bloodiest battle alone, without even the awareness of others to comfort him. He repeatedly wishes that the boy were with him, but he realizes that his loneliness is a necessary condition if he is to maintain his self-respect" (125).

On his expedition, Santiago is alone and his isolation reflects a choice consciously made: "My choice was to go there to find him beyond all people. Beyond all the people in the world. Now we are joined together and have been since noon. And no one to help either of us" (39). He chooses to go 'out too far' and this leads to his transcendent redemption.

Moreover, Santiago's eighty-four luckless days do not have any effect on his belief and faith that he will once again prove himself as a lucky fisherman and to maintain self-respect. The labeling of Santiago as salao (unlucky) has a damaging effect on him, but his decision to far out into the Gulf shows his great effort. As he explains, "My choice was to go there to find him (the marlin) beyond all people. Beyond all people in the world"(39).

Santiago's journey far into the Gulf evidences his active faith in human effort. He maintains, "Every day is a new day. It is better to be lucky. But I would rather be exact. Then when luck comes you are ready" (23). He does all that within his power to prove himself once again, which for him, would be to catch a large fish and no longer be salao. He shows remarkable effort that he will again be blessed with a good catch. However, the presence of the sharks does not negate the fact that Santiago has actively maintained his faith in his effort. The sharks cannot erase the fact that he has caught the marlin that has helped to restore his character. Santiago's gallant effort is also shown as he dismissed the notion that he is being punished or that he has sinned, though his consideration that he went 'too far outside' suggests that he may fault himself for going so far into the Gulf.

By exploring the aesthetic and thematic aspects of The Old Man and the Sea, Hemingway's understanding of man becomes apparent. Santiago's tranquility and majesty seem to have sprung from the mind of a completely different writer. Although Santiago's solitude in the midst of his battle with the marlin has an epic dimension, he is never selfpitying in his isolation. Rather, Santiago's isolation is reduced.

Santiago is trying to find himself again. He is attempting to know who he is in the present. He knows what he was in the past, and yet even though his body has aged, the dreams of youth persist; saying "But who knows? Maybe today. Every day is a new day" (23). 
Perhaps Santiago's feeling toward his role as a fisherman is the most influential factor of his majesty. He must capture the great fish to maintain his sense of confidence and pride as a man:

"I'll kill him though," he said. "In all his greatness and glory."

"Although it is unjust," he thought. "But I will show him what a man endure."

"I told the boy I was a strange old man," he said. "Now is when I must prove it." (53)

However, Santiago justifies his killing by claiming that is what he has to do as a fisherman and it is not a sin if you love him (88). His job as a fisherman and his love for his profession justify his killing, therefore he is described as a caring and even benevolent man who feels sorry about his act of killing. His relationship with his prey is intimate. He addresses the fish: "I love and respect you very much. But I will kill you dead before this day ends" (43).

Besides that, Santiago's vocation as a fisherman helps to show his majesty; it exposes that there is something more than food and survival in the killing. Hemingway writes: "You did not kill the fish only to keep alive and to sell for food, he thought. You killed him for pride and because you are a fisherman. You loved him when he was alive and you loved him after. If you love him, it is not a sin to kill him. Or is it more?" (88-89). Santiago is not sure of it is a sin, because he killed the marlin 'for pride,' the pride of endurance, and something more; he killed the marlin to show what a sort of a man he is (53).

Santiago perceives himself as a unique and different person from other people. However, what differentiates Santiago from others is his endurance of spirit and his effort. He is well aware that refusing to admit to suffering is somewhat strange. He tells Manolin that he is "a strange old man" (48), but he resolves to act strangely once again and to show the marlin and himself: "What a man can do and what a man endure" (53). And we came across another description when Santiago tells Manolin early in the story: "I have resolution" (15), though his sail may appear as a symbol of "permanent defeat" (3), but he will not subjugated. He distinguishes himself from other fishermen who "feared being out of sight of land in a small boat" (49). He is determined to sail "far out" in his search (20). Another majesty of human effort appears when Manolin asks Santiago whether he is really "strong enough for a truly big fish?" (7), the old man explains that, even if he no longer has his youthful vigor, he does have the experience of years to support him: "there are many tricks" available for a seasoned fisherman (8). Moreover, when the Mako attacks the marlin, the old man shows a noticeable respect for it, saying to himself that the Mako "is not a scavenger" (89). Instead, he adds that the Mako is "beautiful and noble and shows no fear for anything" (89).

Hemingway, through all the events and characters presented in a way, tries to show the majesty of man. His characters are in a constant state of preparation and planning, ever ready and ever hoping to encounter good luck. He brilliantly portrays human effort through the character of Santiago. He presents man as majestic, contrary to other creatures or universe elements. This approach makes man claim everything for him, forgetting that others are separate self-balancing entities. However, it is only Santiago, who, in spite of his loss, willingly endures extended periods of suffering in order to fulfill his responsibilities. Santiago's glory also comes from his understanding of his role with the larger unity of the world that extends to the sun, moon, and stars. The death of the marlin, within that sphere, is the death of an equal. As Santiago says, "I have killed this fish which is my brother" (95).

\section{Discussion}

Hemingway's novel, The Old Man and the Sea, is the story of an epic struggle between an old fisherman and a great fish, called marlin. It is about how this old fisherman struggles for triumph in a world that seems to destroy him. This may be the effect of the fishing experience on the writer, which provided an essential background for the vivid descriptions of the fisherman's effort in The Old Man and the Sea. The novel also highlights how this majesty in human tries to control everything, including nature. Santiago did fight to bring back the marlin in order to show off his superiority. He does everything he can to force the prize of effort.

Hemingway has brilliantly shown the majestic nature of man. Man in desire of triumph moves on to destroy everything, even the very source of his existence. With the help of this old fisherman, Hemingway tries to picture the destruction which the inherent pride in man has led to his eventual downfall. In fact, the novel is all about the effort of man to turn loss into gain, defeat into triumph, and even death into life. The old man becomes the representative of the culture and civilization from which he has come. Even while living away from the civilized world in the folds of nature, he runs into struggle and ends up in gaining victory.

Santiago is characterized as someone struggling against defeat. But he refuses defeat at every turn: the old man decides to sail out beyond the other fishermen to where the biggest fish promise to be. He lands the marlin, tying his record of eighty-seven days after a brutal three-day fight, and he continues to avoid sharks from stealing his prey, even though he knows the battle is useless.

From the very beginning of the novel, we can find traces of this majestic aspect of man. Santiago lives according to his own observation: "man is not made for defeat... [a] man can be destroyed but not defeated" (87). The language used here itself defines the characteristics of man. The old man immediately remembers the eternal law: "they must kill or be killed'.

The first thing Santiago thinks about is to struggle against defeat. It is exactly through the effort to battle the inevitable that a man can prove himself. Indeed, a man can prove this determination over and over through the worthiness of the opponents, he chooses to face, so that Santiago finds the marlin worthy of a fight, saying "Fish, I love you and respect you very much. But I will kill you dead before this day ends" (43). 
At the start, the story focuses on one man's heroic struggle with nature. Richard Damashek remarks about a heroic testimony to that person's endurance and courage, saying: "The old man puts up a fierce and superhuman effort against the great marlin" (2). Santiago fishes alone in a skiff boat on a Gulf Stream and has gone eighty-four days without catching a fish and is enduring the scorn of some fishermen in his village who make fun of him. He resolves to go 'far out' to sea next morning in hopes of catching a big fish. After a while, he hooks the marlin, and the fish starts to drag the boat steadily northwest, but when the marlin begins circling in the water, Santiago drives the harpoon into the fish's side, then it dies, and the sharks start to attack and devour the marlin's meat, leaving only skeleton, head, and tail. Santiago finally returns home to the warmth and friendship and respect of his friends and acquaintances. Clinton S. Burhans, Jr. states:

...if the old man leaves society to go 'far out' and 'beyond all people in the world,' the consciousness of society and of his relationship to it are never for long out of his thought; and in the end, of course, he returns, to his 'good town,' where he finds it pleasant 'to have someone to talk to instead of speaking only to himself and to the sea.' (266)

The Old Man and the Sea portrays a world fill with struggle, pain, and loss, but also shows how a human being may find meaning in such a tragic world. Santiago refuses yielding to depression. After the marlin jumps out of the water "more than a dozen times" (69), fearless and confident, he tells himself, "You better be fearless and confident yourself, old man" (69). His majesty is shown when he takes great pride in performing his task with precision and integrity. He resolves to remain true to his vocation which extends beyond his determination to outlast the marlin to his determination, to save the marlin from the attack of sharks once the marlin is tied to the small boat. When Santiago sees the first shark -- a big Mako -- approach, "his head is clear and good and he is full of resolution" even though he "has little hope" (85). He has little hope because he knows that the marlin's blood will attract many other sharks. Later, Santiago tells himself, "You violated your luck when you went too far outside," but reconsiders and says, "Don't be silly" (98).

Santiago's majesty emerges again when he questions the goals and methods of his profession. He ultimately accepts the suffering engendered by his fight to land and save the marlin. After enduring the pain, he "sits on the unstepped mast and sail and tries not to think, but only to endure" (35). In spite of his efforts, Santiago suffers "plenty" (106) during his three-day struggle with the marlin, but through his battle with the sharks, he summarizes his attitudes toward suffering when he states: "Man is not made for defeat. A man can be destroyed but not defeated" (87). True to his statement, Santiago shows his majesty.

Hemingway, in the end of his novel, tries to portray the kind of human majesty, when Santiago eagerly tries to reestablish his working relationship with the fishermen in his village, including Manolin, and to renew his relationship with the natural world. These values are realized and affirmed by Santiago when he re-experiences the pleasure and struggle related with vocation.

\section{Conclusion}

To regard Santiago as a simple Cuban fisherman is an overly naïve response, though the narrator says of Santiago, "He was too simple to wonder when he had humility" (7). After tracking his efforts for three days, we must conclude that either Santiago is far from simple, or that all human beings, scrutinized sufficiently, are far from simple. Santiago is not proud of his reduced circumstances, but his internal integrity is untouched by his current lack of luck and there is no 'true loss'.

Santiago exhibits saintlike qualities; he exemplifies a form of the humanity. In the story, the strange feeling is caught up with the job of fishing, a job that becomes almost sacramental, as Santiago performs it with a certain dignity, grace, and ritual, finally taking the life of his prey. He is an example of human effort in his embodiment of values of hope, hard work, and persistence. In spite of his being a 'poor' person, living in a shack where he uses his pants stuffed with newspapers for a pillow at night, he relies on himself for his survival and believes in his ability and experience as a fisherman. Though the sharks devour his catch, Santiago is not defeated at the end of the story. Although he lost the marlin to the sharks, he keeps the spirit and determination to fish again, planning future fishing expeditions with the boy. He retains hope and a belief in the future to the end. Philip Young writes of Santiago: "He is undefeated, he endures, and his loss, therefore, in the manner of it, is itself a victory" (125).

However, this human majesty is characterized by individual courage, will, endurance, precision of emotion and initiation when Hemingway stresses on admirable human qualities and inevitable human conditions. As Carlos Baker states about Hemingway's fiction: “Under all [Hemingway's] brilliant surface lies the controlling Dichtung, the symbolic underpainting, which gives so remarkable a sense of depth and vitality" (289). Hemingway himself once said about The Old Man and the Sea: "I tried to make a real old man, a real boy, a real sea and a real fish and real sharks. But if I made them good and true enough, they would mean many things" (qtd. in Donaldson 249).

A critic, Mark Schorer, considers The Old Man and the Sea as a parable when he points out: "This appears to be not only a moral fable, but a parable and all the controlled passion in the story, all the taut excitement in the prose come, I believe, from the parable" (19-20). So that, Santiago is not simply the protagonist of the novel; instead, he is the story. 
Hemingway's The Old Man and the Sea, at the end, appears to have mystical qualities, qualities that caught the attention of the readers as well as literary critics. This work is distinguished as a first rate piece of fiction. Santiago's story is a story of suspense. When he hooks the marlin and announces its size, saying "He can't be that big?" (75), the reader is also hooked and carried through the joys and sufferings that pervade the entire story. Santiago's story is a story of man against himself, against nature in all its majesty. It is a story of an old man against nearly impossible odds. Hemingway, in Santiago's story, makes the improbable possible and believable, through his masterful handling of the tale.

\section{References}

Baker, C. (1973). Hemingway: The Writer as Artist. Princeton, N. J.: Princeton Univ. Press.

Burhans Jr., Clinton S. (1999). “The Old Man and the Sea: Hemingway’s Tragic Vision of Man.” Bloom's Modern Critical Interpretations: The Old Man \& The Sea. Ed. Harold Bloom. Philadelphia: Chelsea House Publications.

Damashek, R. (2010). The Old Man and the Sea. Ipswich: Salem Press.

Donaldson, S. (1978). By Force of Will: The Life and Art of Ernest Hemingway. New York: Penguin.

Hemingway, E. (2002). The Old Man and the Sea. Beirut: Typo press.

Price, D. (1983). Santiago, The Fisherman-Artist: Autobiography and Aesthetics in "The Old Man and the Sea." Oklahoma: Oklahoma State University.

Schorer, M. (1952). With Grace Under Pressure. New Republic, 6(1), 19-20. Print.

Young, P. (1966). Ernest Hemingway: A Reconsideration. University Park: Pennsylvania State UP.

Weeks, R. P. (1957). Hemingway and the Uses of Isolation. University of Kansas XXXIV (119-125). Print. 